\title{
Ecosystem Services Assessment after 13 Years Restoration Program in the Janitri Water Spring Conservation Area at Batu City
}

\author{
Abban Putri Fiqa ${ }^{1,2}$, Titut Yulistyarini ${ }^{2}$, Endang Arisoesilaningsih ${ }^{3}$ \\ ${ }^{1}$ Master Program of Biology, Mathemathics and Sains Faculty, Brawijaya University, Malang \\ 2Purwodadi Botanic Garden-Indonesian Institute of Sciences \\ ${ }^{3}$ Department of Biology, Mathemathics and Sains Faculty, Brawijaya University, Malang
}

\begin{abstract}
Janitri water springs conservation area was restored by local government on 2004, with local and others plants based on recommendation of community around the area. The objective of the research is to evaluate the restoration success by comparing the vegetation, soil biophysics condition and ecosystem services provided in the restored area, secondary forest, and agricultural land as a positive and negative control. Result shows that the diversity index for trees, sapling and groundcover in the restored area (tree: 1.55; sapling: 2.61; groundcover: 2.71) have the higher value than in the secondary forest (tree: 0.79 ; sapling: 2.30; groundcover: 2.33 ), although its density value is lower than in the secondary forest. The vegetation quality in the restored area is much better than in the agricultural land. Soil and bulk density in the restored area are higher than in the secondary forest and lower than in the agricultural land. Infiltration rate in the three areas was not significantly different, however secondary forest has the highest value, while the C-stock in the secondary forest almost four times than in the restored area. The restoration that have been done, has already increase the diversity, soil biophysics characteristic, and its ecosystem services in the restored area, however the restoration process should be monitored frequently to keep the restoration activity run as planned.
\end{abstract}

Keywords: Ecosystem services, Janitri water spring, Restoration, Soil biophysics, Vegetation

\section{INTRODUCTION}

One of the serious threats for Indonesian diversity is the continued increase of the agricultural land area, especially in the mountains area. Mountains area is important area as a catchment area. Based on reports from the Ministry of Forestry and other environmental agencies, most of the forest land use change is to be used as agricultural land and plantations, and for other functions such as settlements [1]. Besides affecting on structural and landscape change, the land use change also have an effect on changing the ecological function of the area [2]. Changes in forest land into critical land that is not utilized due to logging activities both legal and illegal absolutely necessary repairs to restore the function of the forest as it should. The process that can be done is called restoration activities.

Restoration is an activity undertaken to restore a degraded area thus reverting closer to its original form in the past, not only functionally, but also restoring the diversity of flora and fauna that once existed in the area $[3,4,5]$. Basically,

\footnotetext{
Correspondence address:

Abban Putri Fiqa

Email : abbanpf@gmail.com

Address : Master Program of Biology, Mathemathics and Sains Faculty, Brawijaya University, Malang
}

the succession process can take place naturally in its function for land recovery. However, the natural succession without human intervention often does not work as it should. The succession process often ends with the emergence of novel ecosystem that are even much different from the previous ones [6,7]. Restoration is a big and complicated activity which is takes a long time. Oftenly, due to the length of the restoration process, monitoring activities are rare to be done, even it is known that the restoration process requires frequently monitoring to avoid the development of the ecosystem into an unexpected direction [8].

The simplest monitoring of the restoration process is to evaluate both the diversity and vegetation structure that grows in the restoration area, compared to the reference area chosen as a consideration to know the progress of restoration process $[5,9]$. Sometimes, land coverage by vegetation is considered sufficient to declare that restoration has been successfully done. In fact, the success of the restoration also needs to be assessed by how much improvement the ecosystem services provided by the region $[10,11]$. Ecosystem services are the benefits that can be taken by humans over the processes and resources available in nature, in four different categories which is regulating, provisioning, supporting and cultural $[12,13]$. 
The Janitri water spring conservation area, restored in 2004 by the East Java Local Government with local plantations and some plants from the community recommendation, to avoid the getting worse of environmental impacts due to the logging and agricultural extensification activities [14]. Restored area is located in the Janitri water spring conservation area which is surrounded by agricultural land and people settlement [15]. After 13 years of restoration, it is important to evaluate and monitor the activities that have been done to find out how much the improvement of ecosystem services in the area. Research was carried out to determine the structure and quality of vegetation in the restored areas, as well as the ecosystem services it provided, as compared to the reference area which are secondary forests as positive controls and agricultural lands as negative controls. The results of the study are expected to provide information for stake holders as a reference for the next management of the area.

\section{MATERIAL AND METHOD}

\section{Study Site}

Research was held in the three areas which is restored area, secondary forest, and the agricultural land, located in the Sumber Brantas Village, Batu City, East Java. Geographical position of restored area is located between $07^{\circ} 44^{\prime} 97,2^{\prime \prime} \quad S$ and $112^{\circ} 31^{\prime} 77,4^{\prime \prime} \quad E$, while secondary forest is located in the $07^{\circ} 44^{\prime} 25,4^{\prime \prime} \mathrm{S}$ and $112^{\circ} 31^{\prime} 84,0^{\prime \prime} E$, and the third located, agricultural land located between $07^{\circ} 44^{\prime} 87,3^{\prime \prime} \mathrm{S}$ and $112^{\circ} 31^{\prime} 75,4^{\prime \prime} \mathrm{E}$ (Fig. 1). The area is classified as a wet climate with rainfall $2500 \mathrm{~mm} . \mathrm{th}^{-1}$. The topography condition in the area is various, with elevation from $25 \%$ to $40 \%$. The wide of restoration area is about 3.46 ha or only about $16.60 \%$ from the total area around Janitri water spring based on the micro-watershed delineation that already been done before [15].

\section{Data Collection}

Vegetation evaluation was done by made a 15 plots in each area (restored area, secondary forest and agricultural land) $20 \mathrm{~m} \times 10 \mathrm{~m}$ for trees $(d>30 \mathrm{~cm}), 10 \mathrm{~m} \times 5 \mathrm{~m}$ for sapling $(30>d>5)$, and $1 \mathrm{~m} \times 1 \mathrm{~m}$ for groundcover. Data collected in every plot are plant species, number, frequency, also trees and sapling diameter. In the ground cover plot, abundance was determined as a percentage and destructive action was done to define the wet and dry weight (biomass). This data also used to measure the total C-stock in the area.

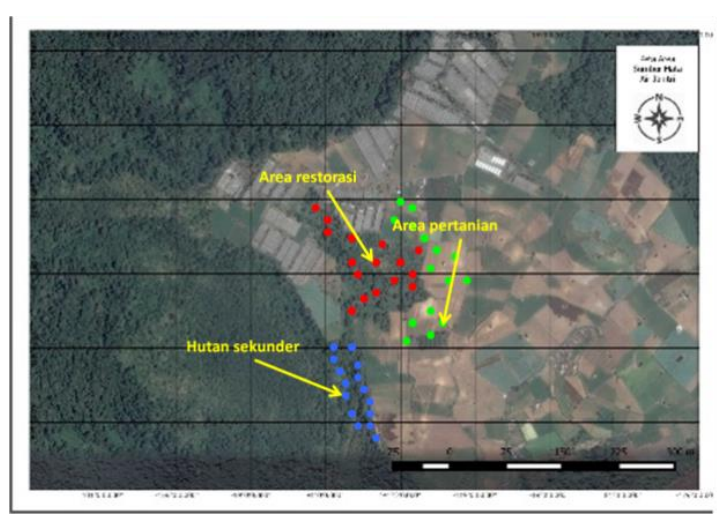

Figure 1. Areas and research plot in the Janitri Waterspring, Batu City, East Java (Google earth, 2017)

Beside the structure and vegetation quality, infiltration rate also been measured in each plot by double ring method on saturated soil condition after the rain. Soil samples were taken at the depth $0-10 \mathrm{~cm}$ with a sample ring to determine soil characteristics. Soil and bulk density determining was done by cylinder method [16], while percentage of C-organic and soil organic matter was determined by using Walkley and Black method [17]. C-organic percentage and bulk density also used to measure the C-stock in the soil.

\section{Analysis Data}

Vegetation data was tabulated and calculated, to find the Important Value Index (IVI), the Shannon-Wiener diversity index $\left(H^{\prime}\right)$. Cstock total in the area was also measured $[18,19]$. Statistic analysis was done by PERMANOVA to find the difference of those three ecosystems. Biplot analysis was done to know the character similarity of the restored area and the reference area, to evaluate the success of restoration program. Statistic analysis was done by software PAST.3.

\section{RESULT AND DISCUSSION \\ Vegetation Structure and Quality}

The structure and quality of vegetation is a major supporting factor in ecosystem services. In the restoration area, there are total 50 plant species from 30 different families were found, which are divided into trees, sapling and ground cover. This is higher than the species richness in the secondary forest which is 41 species from 30 families. In contrast to the first two areas, agricultural land tends to have low species 
richness, which is only six and all of them are vegetable crops. Based on the vegetation analysis, it can be seen from the Important Value Index (IVI), there is dominance of species Engelhardtia spicata, both in tree and sapling in two observed location that is restored area and secondary forest (Fig. 2). IVI value of Engelhardtia spicatain the restored area for tree is $141.80 \%$ and $65.22 \%$ for sapling. In addition, in the secondary forest, IVI value of Engelhardtia spicata for tree and sapling respectively are $217.82 \%$ and $75.83 \%$. Trema orientalis and Casuarina junghuhniana also have a high IVI value for tree $49.50 \%$ and $19.58 \%$ respectively in the restored area, while in the secondary forest is $20.08 \%$ and $27.73 \%$. This three trees species is a origin species in this area that might be adaptive in the lower mountain area climate with the altitude more than $1200 \mathrm{~m}$ asl $[20,21]$. However, unlike the pattern shown by E. spicata, either $T$. orientalis or $C$. junghuhniana only found in sapling form in a small number. E. spicata is one of the native species for mountainous ecosystem [5]. The condition should become a concern to conserve the nature as origin as possible, considering that the different structures and compositions of vegetation will produce different types of ecosystems [22].

Trees and saplings plot are only available in the restored area and secondary forest. Neither trees nor saplings were found in the agricultural land, while ground cover plot were exist in all three area.

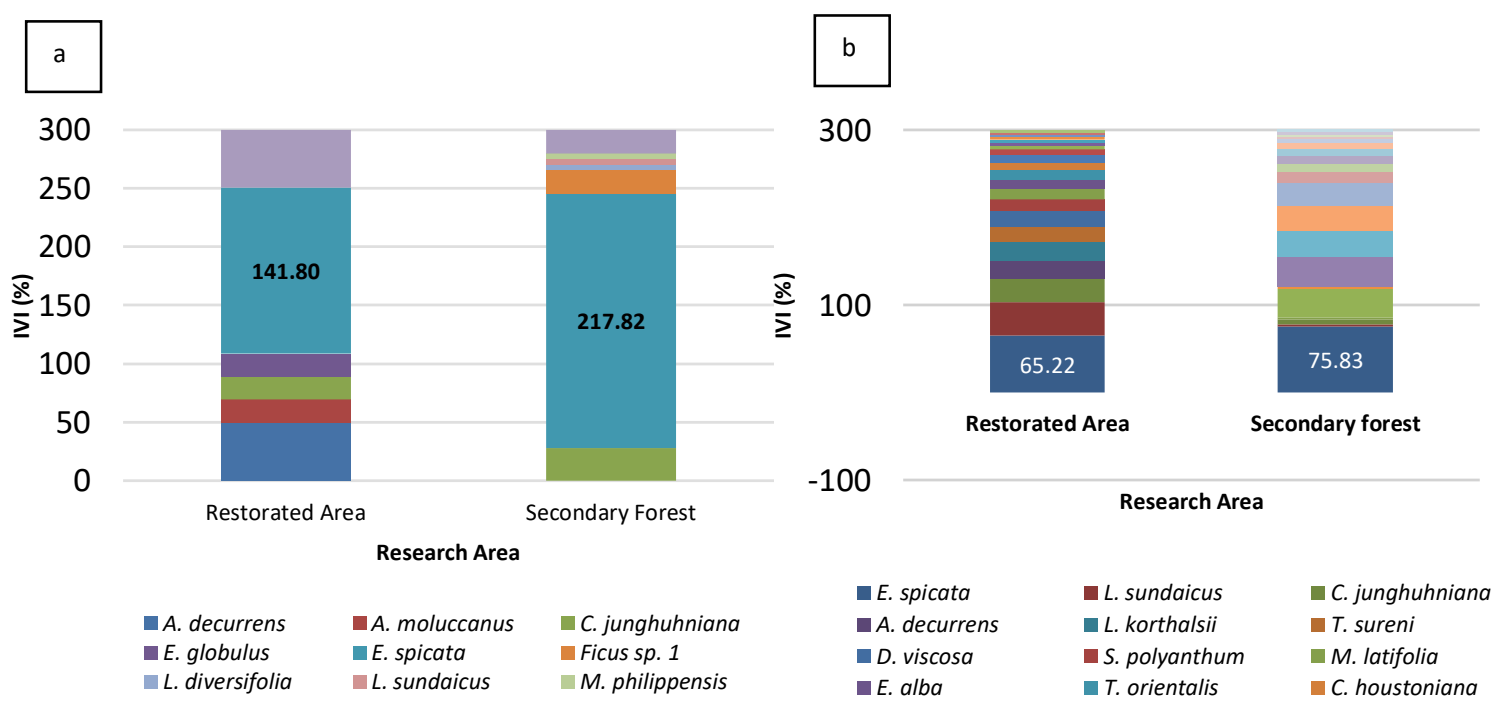

Figure 2. Vegetation composition and Important Value Index; a). Trees; b). Sapling in the research area Janitri water spring, Batu City

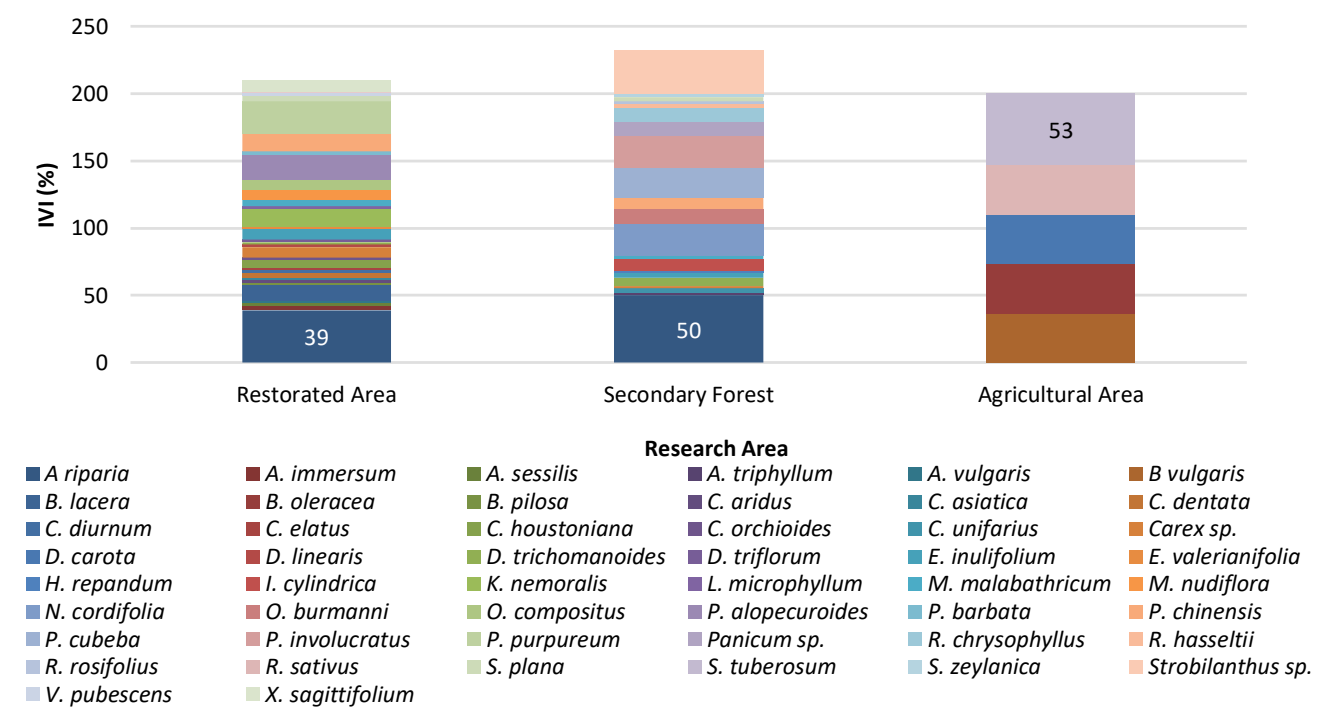

Figure 3. Vegetation composition and Important Value Index (IVI) of ground cover in the Janitri water spring, Batu City 
Ground cover composition both in the restored area and in the secondary forest was dominated by Ageratina riparia, with IVI is 38.84 \%in the restored area and $50,10 \%$ in the secondary forest (Fig. 3). Ageratina riparia is one of the invasive species that should be noticed. A.riparia also been reported become a dominated species in the natural forest areas of Mount Papandayan and the Merapi region after the eruption [23, 24]. A. riparia is an adaptive plant species that is capable to grow as a pioneer, whether shaded or not, as other invasive plant types [25].

Different to the other two areas, there is no domination in the ground cover composition. There are six species found in the agricultural land during rainy and dry season, and Solanum tuberosum has the highest IVI (53\%) since it is found in both seasons, while the other five is not. The Shannon-Wiener diversity index $\left(\mathrm{H}^{\prime}\right)$ of tree in the restored area is classified as a medium $(1,55)$, while in the secondary forest is classified as low $(0,79)$ (Fig. 4). For sapling vegetation type, both of the restored area and secondary forest is classified as medium $1<\mathrm{H}<3$ [26]. Restored area has higher diversity index than the secondary forest, since there are some trees and sapling that been introduced to the area during the restoration program. Some of the species are Persea americana, Acacia deccurens, Syzygium cuminiand also Syzygium polyanthum, that planted as a community recommendation [14]. It could define that the diversity quality in the restored area is better than in the secondary forest and in the agricultural land.

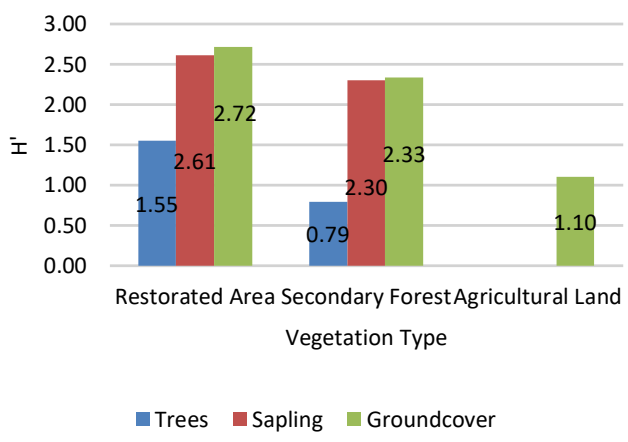

Figure 4. Shannon-Wiener diversity index in the three research area

Generally, the diversity index in the mountain area is lower than in the low land forest. The presence of domination of some species also become a characteristic from the mountain area, either on lower mountain (1200 - 1800 a asl) or in the higher mountain (1800-3000 $\mathrm{m}$ asl). The higher the elevation of the area, the lower plant diversity it has [21].

\section{Soil Biophysics Characteristic}

Soil biophysics parameter that been observed in this research are bulk density, soil density, Soil C-organic percentage and organic matter percentage. The value of soil and bulk density is always in line. Based on the statistical analysis that been done, the average value of the soil and bulk density in the agricultural land is the highest and significantly $(p<0.05)$ with the other two area, with the value $0.68 \mathrm{~g} . \mathrm{cm}^{-3}$ and $2.22 \mathrm{~g} . \mathrm{cm}^{-3}$ respectively (Fig. $5 \mathrm{a}$ and $5 \mathrm{~b}$ ). While the lowest is in the secondary forest $\left(0.36 \mathrm{~g} . \mathrm{cm}^{-3}\right.$ and 2.27 g. $\left.\mathrm{cm}^{-3}\right)$. Agricultural land is an area with high human activity, and this impact on the soil and bulk density, which is also higher. The opposite, in the secondary forest with low human activity will cause the soil and bulk density also low, although secondary forest in this area is already categorized in the degraded category. Soil and bulk density related with the soil porosity, which is mean the higher soil density, the lower soil porosity and will give impact to water infiltration to the soil, it is mean that water will be harder to percolate to the soil $[27,28]$.

The value of Carbon and other organic matters in the restored area has the lowest value. The percentage of C-organic and organic matter in the secondary forest are $17.94 \%$ and $30.93 \%$ (Fig. 5c and 5d). C-organic percentage in the agricultural land is $17.94 \%$, or four times in the restored area, while the percentage of organic matters is three times from the restored area with percentage $7.04 \%$. This condition might be happen due to the fertilizer activity that has been done by the farmer to increase the soil fertility in the vegetable farming area, to increase the vegetable product.

\section{Ecosystem Services}

The infiltration rate is one of the ecosystem services provided by an ecosystem. The infiltration rate is also closely related to the soil biophysical conditions measured. The value of infiltration rate in the secondary forest observation plot, has the highest value, which is $56.23 \mathrm{~cm} \cdot \mathrm{h}^{-1}$ based on the statistical analysis performed $(p<0.05)$, the value is significantly different from the other two areas (Figure 7). The value of infiltration rate in the restored area and agricultural land according to the variance test, was not significantly different, although the 

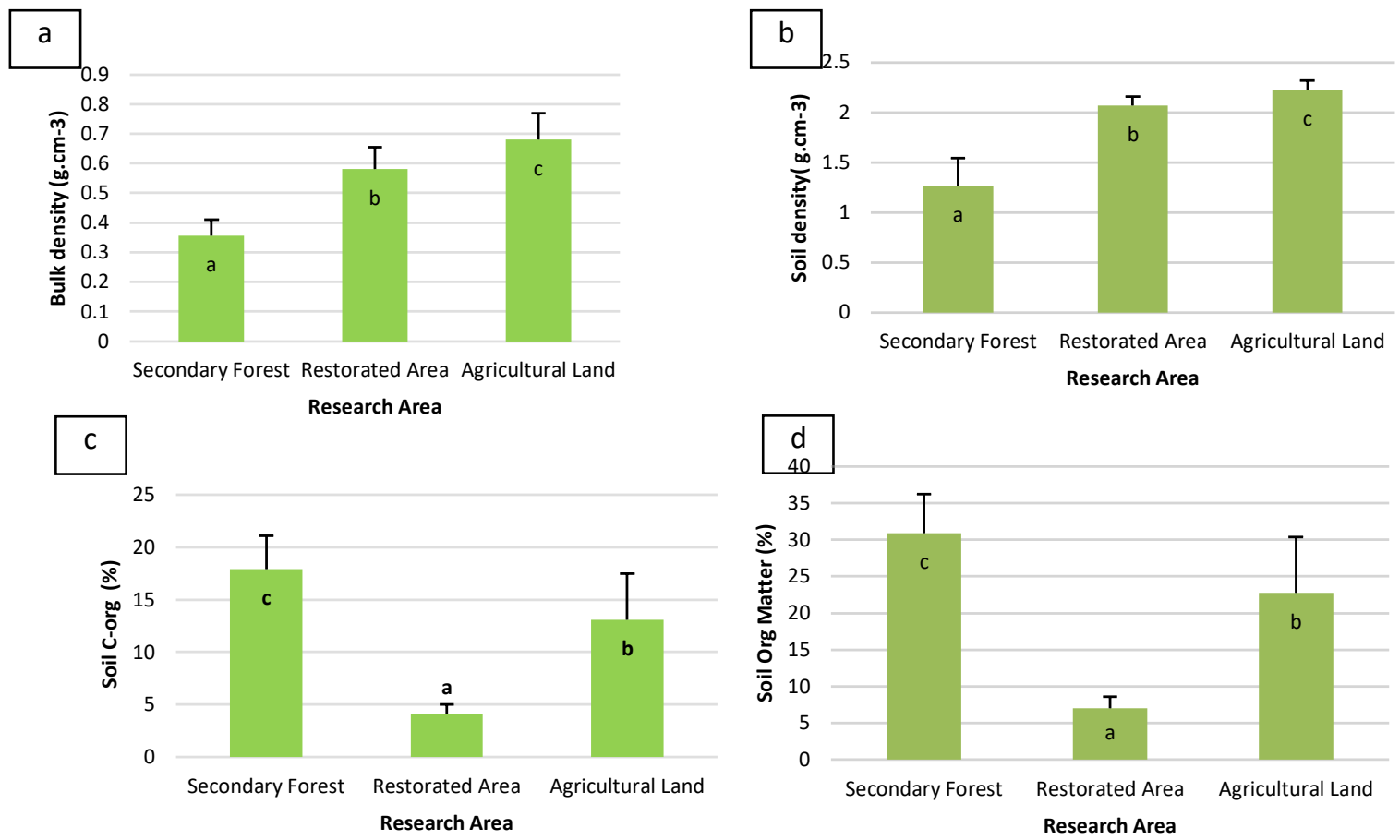

Figure 5. Soil biophysics parameter a).Bulk density; b.) Soil density; c). Soil C-organic; d). Soil organic matter in the Janitri Water Spring, Batu City (Note: Different notation shows different significantly with $p<0.05$ )

average infiltration rate in the restoration area was higher at $33.51 \mathrm{~cm} \cdot \mathrm{h}^{-1}$ compared to 20.76 $\mathrm{cm} \cdot \mathrm{h}^{-1}$ on the farm.

The value of infiltration rate is related to the soil and bulk density values of the soil in an area. High value on both soil and bulk density will cause the porosity of the soil decrease, so that the speed of water entering the soil will also decrease $[27,28]$. The rate of infiltration is also influenced by the above ground vegetation. Changes in land use will affect the infiltration speed of a land [29]. As is known, the rate of soil infiltration will be helpful in minimizing erosion, and increasing the availability of groundwater [27].

Carbon stored in the area is also one of the most scalable ecosystem services in evaluating the success of restoration. Secondary forest plots have the highest carbon stock compared to the other two areas. This can be seen from the highest biomass value. The total value of carbon stocks in the secondary forest reached 129.47 ton. ha ${ }^{-1}$. This value is nearly four times greater than the value of carbon stocks in the restored area 36.60 ton.ha $^{-1}$ (Fig. 8). The value of below ground carbon stocks in agricultural land is highest (86.78 ton. ha ${ }^{-1}$ ) compared to other areas. This is due to the high value of bulk density, which affects the soil weight and also the percentage of C-organic in soil which is also high. The value of carbon stocks in the restored area is still quite low compared to other areas. The carbon stock in Ngantang degraded forests shows a value of 161 ton.ha ${ }^{-1}$, whereas in natural forest, the value is 297 ton. $^{-1} a^{-1}$ [30].

The Profile of Janitri Water Spring Conservation Area after 13 Years Restoration Program

The statistical test conducted at three research sites shows that the location of the research influences the parameters tested. Secondary forests have the greatest value and differ significantly compared to the other two locations. The restoration area has several characters that almost resemble the characters in the secondary forest; some even better such as the species richness of the trees, saplings, and ground cover. However, some of the soil biophysical values and ecosystem services are still lower than in agricultural land. The condition of ecosystem services will get better as time increases, and also as increasing of litter decomposition and the biomass in the area with condition that the restored area is not disturbing much.

Restoration program is a complex with a long time duration activity, and also requiring a continuous monitoring process. For 13 years, the restoration process in Sumber Janitri 


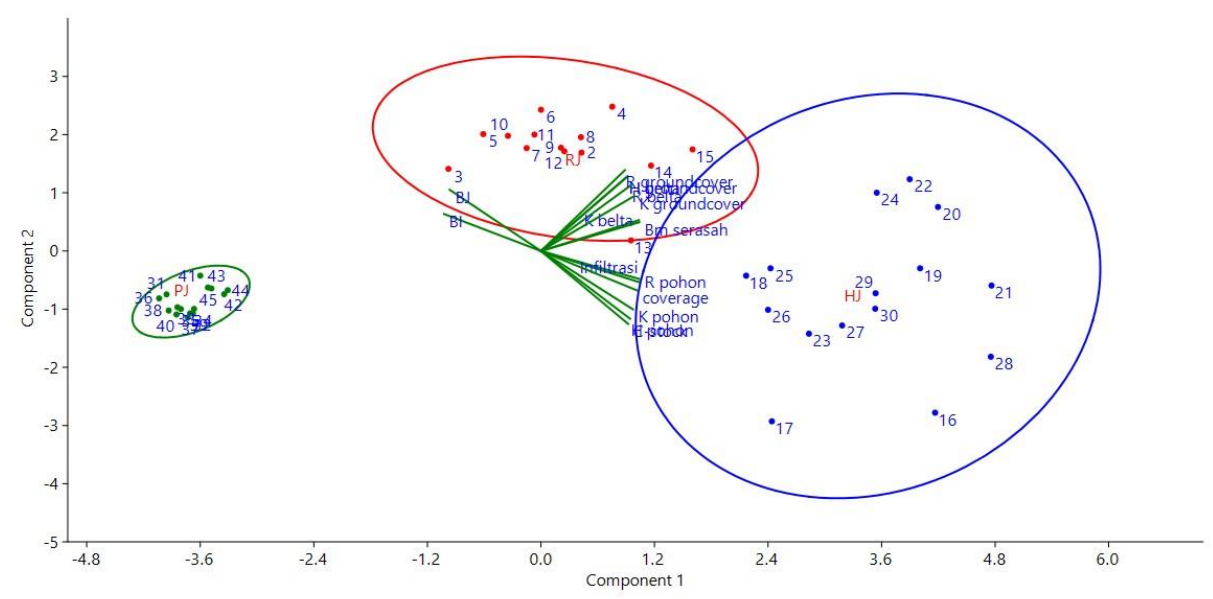

Figure 6. Ecosystem Profile of Restored Area (Red), Secondary Forest (Blue) and Agricultural Land (Green) in Janitri Water Spring, Batu City based on the biplot analysis (Note: PC $1: 74,44 \%$, PC $2: 20,43 \%$ )

conservation area has achieved considerable progress. Based on statistical tests with biplot, it is known that the ecosystem in the restoration area (RJ) has proximity to secondary forest (HJ) as reference area, compared to farmland (PJ), as negative control (Fig 6). The observation plots in the restoration area have similar characteristics to secondary forests, especially on the structure and quality parameters of vegetation, soil biophysical conditions and ecosystem service values.

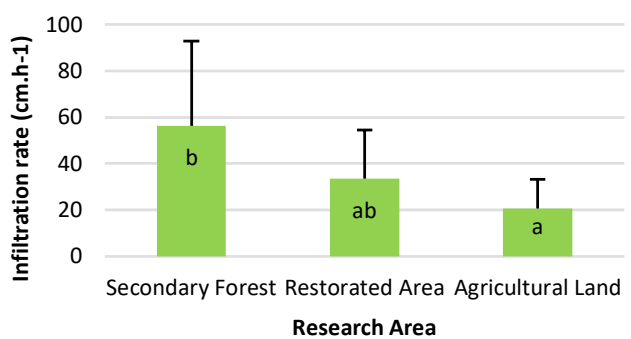

Figure 7. Infiltration rateon the Janitri water spring area, Batu City (Note: Different notation shows different significantly with $p<0,05$ )

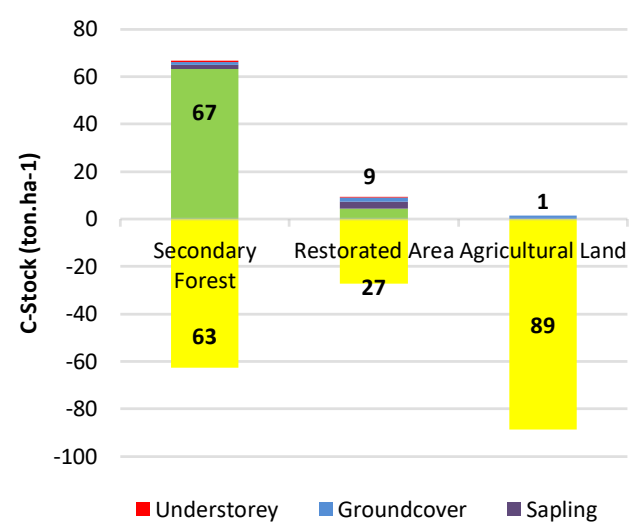

Figure 8. Carbon storage in the Janitri Water Spring area, Batu City

\section{CONCLUSION}

The restoration area based on the research result generally has already resembled the characteristics of the secondary forest as the reference area. The diversity index of restored area is even higher than in the secondary forest. However, some shortcomings, such as the low value of ecosystem services in the form of carbon stocks and infiltration rate, are expected to increase and resemble the value of environmental services in secondary forests as time goes on. The existence of invasive species within the area and the absence of seedlings in some native plants should be of concern in the management of the restored area. Periodic monitoring is required to keep the area in order for the restoration to proceed as expected.

\section{8-6,6-7,7-8}

\section{REFERENCES}

[1]. Narendra, B.H., 2009. Alih Fungsi (Konversi) Kawasan Hutan Indonesia: Tinjauan Aspek Hidrologi dan Konservasi Tanah. Prosiding Fungsi Kawasan Hutan. Balai Kehutanan Mataram.

[2]. Hu, H, W Liu and M Cao. 2008. Impact of land use and land cover changes on ecosystem services in Menglun, Xishuangbanna, Southwest China. Environment Monitoring Assessment 146:147-156.

[3]. Pander, J. \& J. Geist. 2013. Ecological indicators for stream restoration success. Ecological Indicators. 30: 106-118.

[4]. Whitten, T., R.E. Soeriaatmadja, and S.A. Afiff. 2000. The Ecology of Java and Bali. Periplus. Singapore.

[5]. Hakim, L \& H. Miyakawa. 2013. Plant tree species for restoration program in 
Ranupani, Bromo Tengger Semeru National Park Indonesia. Biodiversity Journal, 4(3), 387-394.

[6]. Choi, Y. D. 2004. Theories for ecological restoration in changing environment: Toward 'futuristic' restoration. Ecological Research. 19: $75-81$.

[7]. Hobbs, R. J., E. Higgs \& J. A. Harris. 2009. Novel ecosystems: implications for conservation and restoration. Trends in Ecology and Evolution. 24 (11):599-605.

[8]. Suding, K. N. 2011. Toward an Era of Restoration in Ecology: Successes, Failures, and Opportunities Ahead. Annual Review of Ecology, Evolution, and Systematics. 42: 465-487.

[9]. Ruiz-Jaen, M. C. \& T. M. Aide. 2005b. Vegetation structure, species diversity, and ecosystem processes as measures of restoration success. Forest Ecology and Management. 218:159-173

[10]. Benayas, J. M. R., A. C. Newton, A. Diaz, \& J. M. Bullock. 1999. Enhancement of biodiversity and ecosystem services by ecological restoration: A meta-analysis. Science. 325: 1121-1124.

[11]. Ruiz-Jaen, M. C. \& T. M. Aide. 2005a. Restoration success: How is it being measured? Restoration Ecology. 13(3):569577

[12]. Wunder S., Thorsen B.J. 2014. Ecosystem services and their quantification: What are ecosystem services? In: Thorsen B.J., Mavsar R., Tyrväinen L., Prokofieva I., Stenger A.(eds): The Provision of Forest Ecosystem Services: Quantifying and Valuing Non-marketed Ecosystem Services. Joensuu, European Forest Institute: 17-20.

[13]. Millennium Ecosystem Assessment. 2005. Ecosystems and human well-being: synthesis report. Washington DC: Island Press.

[14]. Soejono. 2008. Panduan Pengenalan Vegetasi untuk Rehabilitasi Lahan di Sebagian Kawasan Tahura R. Soerjo Jawa Timur. UPT Balai Konservasi Tumbuhan Kebun Raya Purwodadi-LIPI. Pasuruan.

[15]. Yulistyarini, T. \& A. P. Fiqa. 2010. Struktur dan komposisi vegetasi pada lahan hutan tersisa di sekitar Mata Air Janitri, Sumber Brantas, Batu, Jawa Timur. Prosiding Seminar Nasional Basic Science VII. 20 Februari 2010. Universitas Brawijaya. I-429 435.
[16]. Widianto, K. Hairiah, D. Suhardjito, \& M. A. Sardjono. 2003. Bahan Ajar Agroforestri: Fungsi dan Peran Agroforestri. ICRAF. Bogor.

[17]. Walkey, A. \& I. A. Black. 1934. An examination of the degtjareff method for determining organic carbon in soil: Effect of variations in digestion and conditions and of inorganic soil constituents. Soil Science 63: 251-263.

[18]. Krebs. C.J. 1989. Ecology: The Experimental Analysis of Distribution and Abundance. Harper and Row. New York.

[19]. Hairiah, K, A Ekadinata, RR Sari, S Rahayu. 2011. Pengukuran Cadangan Karbon: dari Tingkat Lahan ke Bentang Lahan. Petunjuk Praktis. Edisi ke dua. Bogor World Agroforestry Center, ICRAF SEA Regional Office, Universitas Brawijaya. Malang. 66 p.

[20]. Soejono. 2006. Pengenalan jenis pohon dominan penyusun formasi hutan sebagian wilayah Taman Hutan Raya R. Soerjo Batu, Malang. Laporan Teknis 2006. UPT Balai Konservasi Tumbuhan Kebun Raya Purwodadi-LIPI.

[21]. Whitten, T., R.E. Soeriaatmadja, and S.A. Afiff. 2000. The Ecology of Java and Bali. Periplus. Singapore.

[22]. Budiharta, S. 2010. Floristic composition at biodiversity protection area in Lubuk Kakap, District of Ketapang, West Kalimantan. Biodiversitas 11 (3): 151-156.

[23]. Sutomo, D. Fardila. 2013. Floristic Composition of Groundcover $\mathrm{V}$ egetation afterthe 2010 Pyroclastic Fire on Mount Merapi. JMHT XIX (2): 85-93.

[24]. Sulistyawati, E, R.M.Sungkar, E.Maryani, M.Aribowo, D.Rosleine. 2006. The Biodiversity of Mount Papandayan and the Threats. International Interdisiplinary Conference Volcano International Gathering 2006, "1000 years Merapi Paroxysmal Eruption", Volcano: Live, Prospeity, and Harmony. Yogyakarta, Indonesia, September 7, 2006.

[25]. CABI (Invasive Species Compendium). 2011. Ageratina riparia (mistflower). http://www.cabi.org/isc/datasheet/23251. Accessed on 7 June 2017.

[26]. Magurran, A.E. 1988. Ecological Diversity and Its Measurement. Springer. Netherlands.

[27]. Suprayogo, D, Widianto, P Purnomosidi, RH Widodo, F Rusiana, ZZ Aini, N Khasanah, Z Kusuma. 2004. Degradasi sifat fisik tanah 
sebagai akibat alih guna lahan hutan menjadi sistem kopi monokultur: kajian perubahan makroporositas tanah. Agrivita 26 (1): 60-68.

[28]. Prasetya, B, S Prijono, Y Widjiawati. 2012. Vegetasi pohon hutan memperbaiki kualitas tanah Andisol-Ngabab. Indonesian Green Technology Journal Vol.1 (1): 1-6.

[29]. Cram, S., I. Sommer, P. Fernandez, L. Galicia, C. Rios, I. Barois. 2015. Soil natural capital modification through landuse and cover change in a tropical forest landscape: implications for managements. Journal of Tropical Forest Science 27 (2): 189-201.

[30]. Hairiah, K dan S Rahayu. 2010. Mitigasi Perubahan Iklim: Agroforestri kopi untuk mempertahankan cadangan karbon lanskap. Makalah dipresentasikan pada Seminar Kopi 2010. 4-5 Oktober 2010. Bali. 